\title{
Notes on Chaos: Draft Political Treatises
}

\author{
Jan-Erik Lane \\ Public Policy Institute, Belgrade, Serbia \\ Email: janeklane@gmail.com
}

How to cite this paper: Lane, J.-E. (2018) Notes on Chaos: Draft Political Treatises Open Journal of Political Science, 8, 69-80. https://doi.org/10.4236/ojps.2018.82006

Received: February 21, 2018

Accepted: March 26, 2018

Published: March 29, 2018

Copyright (C) 2018 by author and Scientific Research Publishing Inc. This work is licensed under the Creative Commons Attribution International License (CC BY 4.0).

http://creativecommons.org/licenses/by/4.0/

\begin{abstract}
The theory of chaos has hitherto been pursued in the natural sciences. However, it may illuminate some issues in the social sciences too.

\section{Keywords}

Chaos in a Civilization, Chaotic Social and Political Systems, Repercussions of Chaotic Climate Change for Mankind
\end{abstract}

\section{Introduction}

91. Politics as well as social change in the early $21^{\text {st }}$ century have taken a dramatic turn towards instability, change and uncertainty, i.e. towards chaos.

92. This may be observed in domestic politics in several countries as well as in international politics in many domains.

93. The overwhelming fear among citizens and inhabitants is that the idea of progress has played out its role: "Things will never be the same!"

94. The most profound anxiety for the developments in the $21^{\text {st }}$ century stems from climate change that may wash mankind from the surface of Planet Earth.

95. But there are many concerns: collapse of Islam internally, the growth of Euro Islam, the threat of nuclear confrontation in East Asia, the withdrawal of the US from international solidarity, the new imperialism of Russia, the resort to new search for the old nationalism as well as surging populism and the decline of the Left, especially Social Democracy, the politicians' opportunism.

96. I will bring up global warming last, because it is the most lethal source of chaos. It is now unstoppable.

97. The social sciences must start modeling real events with chaos theory, dealing with cataclysmic events and developments (Gleick, 1988).

98. Chaos theory was inspired in the 1960s by Lorenz (1969), who was studying equations applied to climate. He found that a system of three differential equations, coupled with a positive feedback and a negative feedback, could not 
predict the future.

99. Chaotic events and developments stemming from climate change now affect social systems and the household economy, globally. Besides climate chaos, we must analyze both civilization chaos and international relations chaos, inter alia. Is not Brexit chaos politics just like the Trump presidency?

\section{The Koranic Civilization}

91. a. Fort the first time in history, the Shias have the upper hand against the Sunnis. The Arab League appears powerless against the Shias strongholds: Iran, Iraq, Syria and Lebanon, as well as to some extent Qatar.

91. b. No reliable statistics exists on the proportion of Sunnis and Shias in the Muslim civilization. If Turkey is added, then we must also separate between different kinds of Shia as well as of Sunnis. India has probably an equal division of Sunnis and Shias but the Shias are often Ismailia's, or seveners. It is stated that the number of Sunnis is much larger than the number of Shias-80-90 percentages against 20-10, but it is likely an underestimation of the Shias, who may be Twelvers, Seveners and Fivers as well as the Shiites in Turkey.

g1. c. The conflict between Sunnis and Shias has always been there in the Koranique civilization, but it has risen to alarming heights, with the stand-off between Saudi Arabia and Iran.

g1. d. Civil war in the giant Muslim civilization wreaks havoc everywhere; first the Al Qaeda and the IISIS against moderate Sunnis and all Shias; now the confrontation between Sunnis and Shias, involving incredible cruelty-see Yemen.

91. e. The ISIS will kill more people by terrorist tactics, but a major confrontation between Saudi Arabia and Iran would bring gigantic misery to Arabs and Parses. In addition, the Kurdish problem remains unresolved, as always. The Kurds constitute a nation, and they are generally moderate Sunnis.

91. f. The outcome of the civil wars in the Moslem civilization has been a dramatic rise in death from domestic violence and countless casualties among civilians, especially women and children. Why would Muslim leaders tolerate and even support this dire development the last two decades? The Koranic predicament is reminiscent of Christianity with the struggle between Catholics, Protestants and sects. It came to nothing but sorrow.

g1. g. The destruction of Syria and Yemen testifies about the complete absurdity of civil war in our time when conflicts can be brokered by peaceful means, like voting and bargaining. The collapse of Iraq followed the Allied Invasion: Operation Iraqi Freedom-the mistake of mistakes. The goal of removing Saddam Hussein, a Sunni, was to make Israel safer, said a French Arab specialist. Look at the outcome now with Shia hegemony.

\section{Why Kill and Die for Religion?}

92. a. With millions of Muslisms and others dead or molested from the civil wars in the Moslem civilization, the only relevant question is: Cui bono? 
92. b. Terrorists, soldiers, civilians have been killed or damaged for the sake of religion, at least verbally. All this carnage and casualties for the purity of religion directly, or the search for power indirectly?

92.c. Eliminating or badly hurting religious opponents became a daily or nightly preoccupation in the Moslem countries, from Algeria over Turkey to Indonesia, from Nigeria to Somalia. Religious violence is counter-productive and its grand scale has weakened the Muslim civilization severely and hurt even the Koranic belief-system.

92. d. Koranic faith puts no limits to killing, just as Christian faith in history was extremely lethal in its consequences of dissent and opposition. Compare with Buddhist sects, where killing is forbidden and hardly occurs. Why cannot Sunnis and Shias live side by side?

92. e. With Christian developments in fresh memory, why turn the Middle East into Germany of the 30 years' war period? Religious or sectarian conflicts tend to remain indecisive, just causing misery and sorrow, like for the Yemeni children without milk. Are they infidels, deserving death from starvation?

92. f. Although the conflict between Sunnis and Shias data back to the death of the Prophet, recent surge in Islamic violence has to do with the rise of fundamentalism in the $20^{\text {th }}$ century, with 3 men: Mawdudi, Qutb and Faraj. They inspired the AL Qaeda as well as the ISIS, theologically, philosophically and ideologically. They argue that true Islam can be distilled and practiced in today's world. They were completely wrong.

92. g. The 3-Maududi, Qutb and Faraj-initiated the process of political chaos in the Muslim civilization, including Northern Africa.

92. h. There is NO ONE SINGLE ISLAM. Koranic belief is divers, as with all world religions. What the Prophet revealed is not known with certainty, and the Koran was forthcoming late after his death. It is open to different reasonable interpretations, and the messages are sometimes abstruse or even contradictory, pending between ALLAH the merciful and ALLAH the revenger.

92. i. The problem of Theodicy poses major difficulties for Islam. How come ALLAH does not intervene to save the innocent Muslims who die from civil war and terrorism? He is believed to be all mighty, but he stays away, silent/Does he regard Shias as infidels? Who knows?

92. $\mathrm{j}$. The belief in all mightiness is impossible to reconcile with the new theory of the universe. When we have trillions of suns and planets, why would Planet Earth matter? How could ALLAH control the incredible forces operating in the universe?

92. k. Religious beliefs constitute stories or tales, nothing more. People adhere to them because they make up their culture, their ways of life and believing. But people want a peaceful message to adhere to, so that they can get on with their lives on a daily basis. The conflicts with Islam are fundamentally meaningless.

92. 1. The books and pamphlets by Mawdudi, Qutb and Faraj stimulated people like al-Zawahiri and al-Zarqawi to commit crimes against humanity and the Muslims. They also were spread by the Muslim Brotherhood. 
92.m. In his civilization enquiry, underlining the world religions, Maw Weber called Islam "a religion of warriors", explaining its incredibly fast spread from Spain to India. This identification of the Muslim virtuosi was an expression of orientalism, which could please only the fundamentalists Sunni or extremists Shias.

92.n. To Weber (1978), Islam is like Judaism and Christianity an "other-wordly" religion (“jenseitig"). Since ALLAH is all mighty on Judgement Day, why kill or wage war in this world ("dieseitig"), the inner-world that is strictly finate?

\section{Growth of Euro Islam}

93. a. The internal chaos in the Muslim civilization has a counter-part in Europe, where the substantial Moslem groups challenge the established order of nation-states.

93. b. The Moslems are now so numerous in several European countries that the party system has been plunged into chaos.

g3. c. The arrival of millions of immigrants, many Moslems from Africa, Arabia and Central Asia, has provoked a strong voter reaction, focusing upon the nation. Thus, nationalism is back with a vengeance. So-called populist parties have sprung up in almost all countries amidst much higher voter volatility.

93. d. The new populism is a mixture of protest phenomena: anti-immigration, anti-partitocrazia, but it is hardly fascism. The Left has difficulties finding a proper response to populism, Social Democracy declining in some countries chaotically.

93. e. Party politics does not fit the classical Lipset and Rokkan model- "frozen party systems in Western Europe". Instead, elections are hard to predict and earthquake outcomes may happen in several election.

93. f. Regionalism has crushed the myth of European Union identity with its nation-states members. The UK leaves the EU under chaotic form. And a province in Spain claims human rights for its demand for secession, meeting sympathy in Antwerp, Scotland and Lombardy.

93. g. One may await the formation of Islamic political parties in Europe, with explosive implications. In both France and Germany, the Moslems are so numerous that they could change the dominant Western culture in these secular nations.

\section{Decline of the US and Public International Law (PIL)}

94. a. The election of Donald Trump as US president has increased uncertainty in international relations, leading to the brake up of institutions that stabilized world politics. The space left from US withdrawal, initiated by president Obama, has rapidly been filled by Russia, conducting a more aggressive foreign policy, and by China, exporting its successful economic model of market socialism to Africa and Central Asia.

94. b. As the international order among sovereign states is weakly institutionalized, it runs the risk of anarchy. Public international law has expanded much since the end of the Second World War, but its enforcement is still precarious. 
94. c. World politics constitutes a Hobbesian jungle without rules that are stably respected. International anarchy should be tamed by normativity, i.e. rules by institutions like NAFTA, NATO, EU and the UN. But the enforcement of these institutions and their rule making is problematic or hardly fully probable.

94. d. The US is now destabilizing several global or regional institutions like e.g. the COP21 Treaty without contributing anything positive to replace them. US nationalism is likely less effective internationally than US participation in institutions and supporting multilateralism.

94. e. Goldsmith \& Posner (2006) claim that public international law is radically different from domestic/national law, especially in lacking the property of being binding, Goldsmith and Posner state: "The book rejects the traditional explanations of international law based on legality, morality, opiniojuris, and related noninstrumental concepts."

94. $\mathrm{f}$. They provide an instrumental account of when and why nations use international law, when and why they comply with it, and when and why international law changes."

(Goldsmith \& Posner, 2006: 463)

(https://www.law.uchicago.edu/files/files/126.pdf)

94. g. The concept of validity-opinio juris - is a prominent element in the concept of law. Is it really true that domestic law or national law could be binding at the same time as public international law is not? When speaking about the nature of law, one often encounters the idea that law is a set of rules that are enforced? What then about the nature of public international law? Posner completely denies normativity. How could a system of norms that constitute $L A W$ lack entirely normativity?

94. h. Governments would have no obligation whatsoever to comply with PIL Thus, the enforcement is entirely up to the states in the international system that may or may not comply alternative may or may not retaliate against reneging by other governments, all based upon consideration of self-interests. Goldsmith's and Posner's rejection of any obligation with PIL appears drastic. Law, all tend to agree, is a huge ordered set of pairs of norms and their enforcement: Law = (norms, enforcements), where a set of criteria, like the basic norm (constitution) or secondary norms are introduced according to the rule of interpretation operating in the country.

94. i. The basis of national or domestic law in beliefs about subjective validity-normativity-recurs in the structure of international law. Public international law has expanded considerably after the Second World War into several bulks of norms, regulating purportedly interactions between states and protecting mankind. Yet, its claim to universal validity has been a serious issue of contention (Goldsmith \& Posner, 2006, Posner, 2009).

94. j. One finds reminiscences of the classical antimony in the debate on PIL (realism against moralism), as it has evolved after the Great War (Besson \& Tasioaulas, 2009; Dunoff \& Trachtman, 2009; Klabbers, 2009; Crawford \& Koskenniemi, 2012; Posner, 2009). The augmentation of normativity along with the 
process of globalisation has led to a debate about the pros and cons of global constitutionalism (Krisch, 2011; Dobner \& Loughlin, 2012). But the recent US change on PIL has stopped the growth in normativity in international relations.

94. $\mathrm{k}$. The PIL framework has advanced slowly by means of the principle of "muddling through".

The PIL is not planned or designed as a whole set of rules.

Instead it has expanded in scope and range in an incremental fashion. It builds upon the accumulated wisdom of a variety of efforts over a few centuries to codify a set of reasonable rules for the interaction of states as well as the protection of persons.

9. 1. PIL as a spontaneous order in appears in the invasion of Iraq in 2003. The US and UK led invasion of the sovereign state of Iraq violated PIL, as clearly expressed by French foreign minister Villepin in the debate in the Security Council ahead of the start of the war. The reason for the attack proved erroneous, but the wider consequences of the invasion were disastrous to such an extent that it forms one of the catastrophes of human history: millions of Muslims dead or wounded, thousands of American and British killed or molested, the disintegration of whole states, the rise of insurgence, radical Islamic fundamentalism.

94. m. The new interpretation of PIL by Goldsmith and Posner (2006) replaces normativity with mutual advantage or utility:

"The primary intellectual target of Limits is the claim-widespread in earlier generations of international law scholarship and still dominant today-that nations comply with international law for non-instrumental reasons." (Goldsmith \& Posner, 2006: 464)

94. $n$. To the extent that PIL is really law, it is Binding, to the extent that it somehow protects mankind. By defecting from the global warming treaty in Paris 2015, the US throws the entire PIL into question. It has dire implication for climate change governance and policy-making. A uni-lateral approach to global warming would be conducive to chaos.

9. o. The uncertainty and unpredictability in the international anarchy that characterizes international relations has augmented when the US no longer supports the validity of public international law and itself breaks it or reneges upon promises made.

\section{Strategies of Russia and China}

95. a. Both Russia and China have begun filling in the void left by the US withdrawal and new isolationism. It has halted the expansion of normativity in international affairs, as the respect for public international law is on the decline.

5. b. Russia has chosen the strategy of aggression, knowing that it will not be opposed by the NATO. Thus, Russia has annexed the Crimea and in reality Eastern Ukraine. Moreover, it is much involved on the Shia side in the civil war in the Muslim civilization, bringing enormous fire power to Syria, defeating the Sunni-ISIS uproar against Assad. 
95. c The Russian ambition to re-create parts of the Soviet empire is risky, as its economy is weak and underdeveloped. It has been conducive to nervousness on the part of NATO as well as Saudi Arabia. A confrontation over the Ukraine could go nuclear. Russian support for the Shia regimes makes the Middle East instable and violent.

95. d. The strategy of China is entirely different, exporting its successful economic model with Chinese workers together with a massive scale of resources, China being much richer than Russia.

95. e. The penetration of African economies has been conducted by China on a huge scale, targeting infrastructure, communication and mining as well as rare resources like fine wood. Now, the plans for the New Silk Road from Beijing to Istanbul involve massive investments by China in the Khanates in Central Asia, as well as Pakistan and Iran.

g5. f. There are now sizeable Chinese minorities in several African countries, leading the modernization of African economies, contributing both labour, capital as well as know-how and management. China's political influence is also on the rise on the African continent.

5. g. The huge Silk Road project with infrastructure, energy projects and transportation links will carbonize Central Asia. In addition, it puts China in competition with Russia's plans for new influence spheres.

95. h. China has the resources to expand outside. It employs its successful economic model: market socialism. The market socialism model was developed by East European economists in the 1950s and 1960s to counter-act the inefficiencies in the classical planned economy model of Soviet style. However, neither Poland, nor Hungary nor Yugoslavia could make it workable. China succeeded!

95. i. Relying upon brutal market incentives in all markets, inside or outside the country, the overall control rests with the state, or the Communist Party. The Party members benefit much from economic development. So far, nothing seems to shatter the hegemony of the Party and its top officials, said to be very rich. China is primarily interested in economic power expansion abroad, not hesitating to use bribes to African dictators.

g5. j. Under the 21 century Tsar, Russia has become a global problem, focusing on resuscitating Soviet power, although it is weak on all but arms and weapons of mass destruction.

\section{Climate Change Chaos}

96. a. The greatest scare for the future in this century stems undeniably from the danger than climate change develops into a gigantic chaos. There is the possibility of a Hawking irreversibility point in time, when global warming has proceeded so far it is unstoppable. The COP21 project is weak normativity.

96.b. To avoid Hawking irreversibility-Planet Earth becoming too hot and volatile in terms of climate with sea level rise of one meter and more-the UN and the governments of 193 states in the world has created a common pool re- 
gime (CPR) to conduct anti-global warming policy. It has succeeded to enact a COP21 Treaty, obligating the state to accomplish decarbonisation in the $21^{\text {st }}$ century - a rare example of international governance under PIL. If the UNFCCC fails, then mankind will perish.

96. c. All countries in the world have formed a common pool regime (CPR) to save the atmosphere from more GHGs, focusing only upon the $\mathrm{CO}_{2} \mathrm{~s}$. The global decarbonisation plan includes: Halting the rise if $\mathrm{CO}_{2}$ s by 2020 (GOAL I); Reducing the $\mathrm{CO}_{2}$ s by $30 \%-40 \%$ by 2030 (GOAL II); Complete decarbonisation by around 2075 (GOAL III); Decentralised implementation under international oversight, financial support and technical assistance. These are enormous goals, as only one country-Uruguay-is near GOAL I and GOAL II. Some countries have lately had stalling or even decreasing $\mathrm{CO}_{2} \mathrm{~s}$, but many other still face an upward sloping curve.

96. d. Just before the start of the UN global environment reunion COP23 (6-13 November 2017) in Bonn, the study Climate Science Special Report: Fourth National Climate Assessment (USGCRP, 2017) was published in Washington, enquiring into the global warming consequences for especially the US but also the world. It recommends a combination of national and international policy-making to halt temperature rise, despite the fact that the US government is negative. We must then ask: Can decarbonisation policies be implemented or managed? I will suggest: NO.

96. e. Methane emissions are on the rise. Any short-term decrease in methane concentration is improbable: Agriculture emissions increase with the increase of population, the increase in meat diet in developing countries and the temperature increasing the metabolism of microbes in rice agriculture; Wetlands emissions do not diminish with the microbial chemical activity on increase with temperature rise; Melting permafrost releases methane from land and see.

96. $\mathrm{f}$. There has been a widespread hope that the augmentation of $\mathrm{CO} 2 \mathrm{~s}$ would "stall". Yet, China reports ominously that its $\mathrm{CO}_{2} \mathrm{~s}$ are set to increase again, considerably. Large polluters have still upward sloping $\mathrm{CO}_{2}$ curves: India, Indonesia, Australia, Saudi Arabia, etc. Only one country would fulfil the COP21 goals easily, namely Uruguay.

96. g. GHGs have several sources, but the tipping cause is the anthropogenic set of emissions, stemming from energy consumption in a wide sense. The UNFCCC and the governments of the countries of the world want to decarbonize maintain economic growth. They plan to increase the supply of energy by $20 \%$ up to 2040 . This amounts to an impossible goal conflict between the COP21 Agreement and further increased energy consumption. Something hast to give.

96. h. World politician and state leaders cannot sacrifice economic development for decarbonisation, totally excluded by economic establishments everywhere. Poverty would increase, unemployment rise and social unrest spread. The global market economy keeps rolling on, as if there could not occur the Hawking irreversibility. 
96. i. Socio-economic determinism will seal the fate of mankind, as rich countries and emerging economies will not relinquish economic growth. World population is set to add 2 more billions: How to feed? Energy is the source of economic affluence, but how to access energy without GHGs?

96. j. With 90 per cent of energy coming from fossil fuels, and a further 29 per cent increase in energy demand is in the cards, how can the COP21 Treaty goals be fulfilled? Countries can renege at any time, stating they cannot make it for economic or developmental reasons. The COP21 club is a common pool regime (CPR) that is in reality an ocean PD game with an omni present temptation of defection. President Macron wants other countries to pick up the contribution of the US, meaning that US defection was ration (1-N problem). China or India may not wish to make an enormous sacrifice on socio-economic development by cutting 30 per cent of emissions ( $1 / \mathrm{N}$ problem).

96. $\mathrm{k}$. The decarbonisation policies will not achieve the 3 major goals. Instead, the UNFCC would have to take more drastic steps, whatever the consequences for economic growth:

1) Eliminate coal fired power entirely;

2) Build more nuclear power plants, safer ones;

3) Do not take out existing atomic power stations but improve them;

4) Reduce charcoal in the Third World;

5) Stop de-forestation completely, tropical as well as Siberia;

6) Halt the building of numerous dams in the Amazon; preserve the flow of water in great rivers of mankind: the Nile, the Niger, Indus, Ganges, the Mekong, etc.;

7) Build massive amounts of solar power parks and wind power plants.

8) Combat deoxygenation, forcing fisheries to close down in the Southern hemisphere. Tropical fish species in waters with 27 - 29 degrees Celsius will swim in warmer water, but adaption may be impossible, as warm water contains less oxygen;

9) Clean and restore the size of the great lakes of humanity.

\section{Conclusion}

97. a. The recent COP23 reunion in Bonn failed to push the COP21 Treaty into action. Instead, major implementation was delayed to the next meeting: COP24 in Katowice, in Poland, December 2018. Time is running out.

g7. b. Consider the pattern of energy consumption in EU member state Poland (Figure 1).

With this energy mix, Poland is a major contributor to global GHGs. It should change before December 2018.

g7. c. Germany also employs much coal too, despite its Energiewende-see Figure 2.

Germany may very soon wish to change priorities and eliminate all the coal but keep and improve its atomic power.

g7. d. The only solution to the problem of avoiding Hawking irreversibility, 
Energy supply 2015

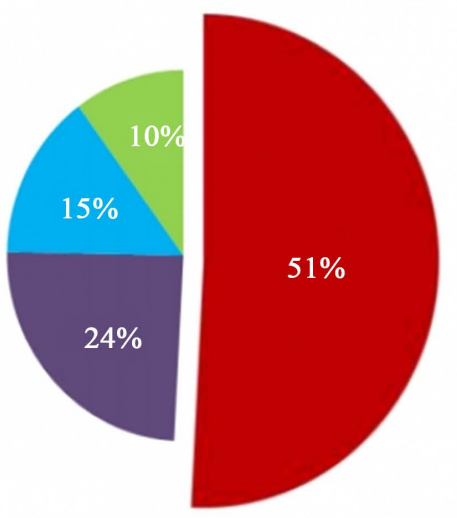

Power supply 2015

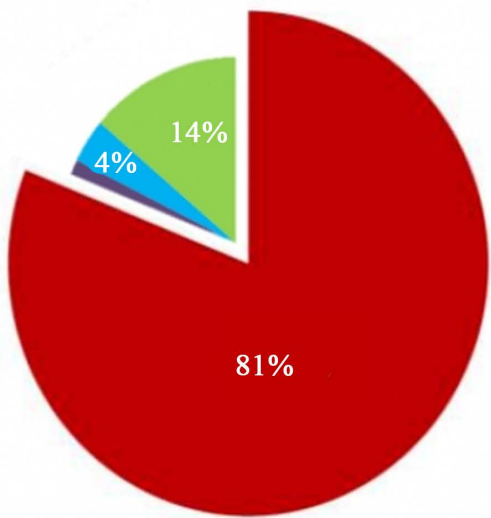

nCoal $₫$ Oil $\approx$ Natural gas $\approx$ Renewables

Coal is the backbone of Poland's energy system: questions over long-term sustainability of the sector must be addressed

Figure 1. Energy mix.

GROSS POWER GENERATION MIX GERMANY 2016 Share of energy sources in German power production

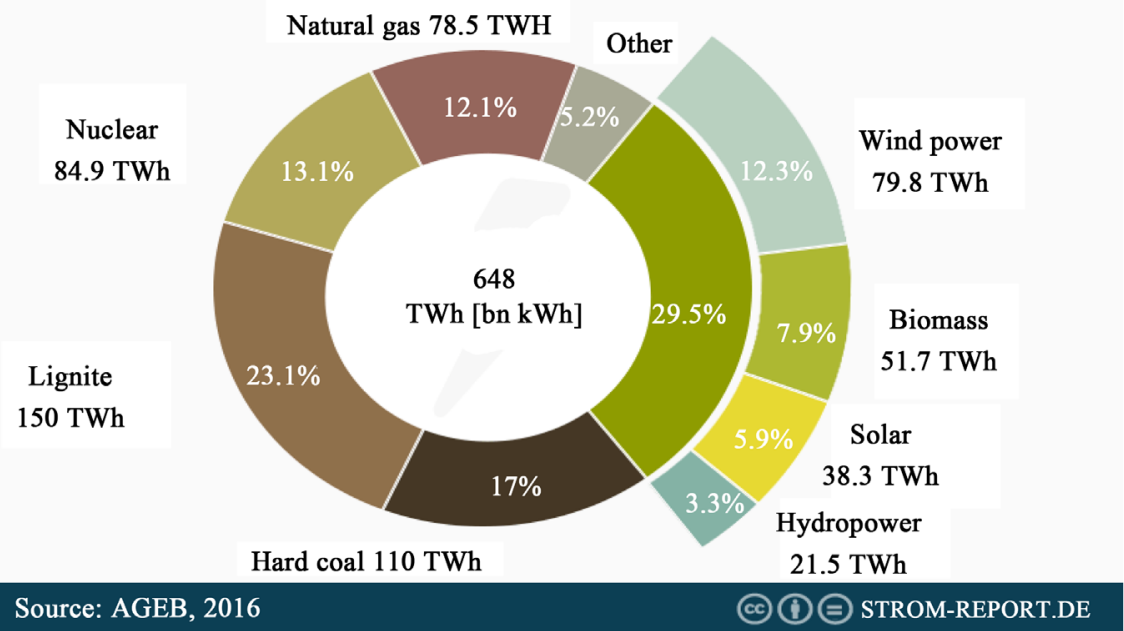

Figure 2. Energy mix.

i.e. total climate chaos is to rely upon solar energy and use electrical vehicles. Referring to the giant solar power station, Quarzazate as benchmark, Table 1 shows what is necessary for decarbonisation now up to 2030.

g 7. e. If or when the COP 21 approach fails, each country will have to rely upon resilience, or the capacity to handle the climate change repercussions. Resilience varies very much, as a country e.g. Bangladesh and Vietnam or Kiribati and Fiji or the Saharan countries, has little of resilience.

9 7. f. Resilience helps to ward off the worst global warming effects, like rising sea level, hurricanes, typhoons, famine, etc. But as climate change grows into full scale chaos, not even much resilience will do. 
Table 1. Number of Ouarzazate plants necessary in 2030 for COP21's GOAL II: (Note: Average of 250 - 300 days of sunshine used for all entries except Australia, Indonesia, and Mexico, where 300 - 350 was used).

\begin{tabular}{|c|c|c|c|}
\hline Nation & $\begin{array}{l}\mathrm{CO}_{2} \text { reduction pledge/ } \\
\% \text { of } 2005 \text { emissions }\end{array}$ & $\begin{array}{l}\text { Number of gigantic solar } \\
\text { plants needed (Ouarzazate) }\end{array}$ & $\begin{array}{l}\text { Gigantic } \\
\text { plants needed } \\
\text { for } 40 \% \\
\text { reduction }\end{array}$ \\
\hline United States & $26-28^{\mathrm{i}}$ & 2100 & 3200 \\
\hline China & $n o n e^{\mathrm{ii}}$ & 0 & 3300 \\
\hline EU28 & $41-42$ & 2300 & 2300 \\
\hline India & none $^{\mathrm{ii}}$ & 0 & 600 \\
\hline Japan & 26 & 460 & 700 \\
\hline Brazil & 43 & 180 & 170 \\
\hline Indonesia & 29 & 120 & 170 \\
\hline Canada & 30 & 230 & 300 \\
\hline Mexico & 25 & 120 & 200 \\
\hline Australia & $26-28$ & 130 & 190 \\
\hline Russia & none $e^{\mathrm{iii}}$ & 0 & 940 \\
\hline Canada & 30 & 230 & 300 \\
\hline Mexico & 25 & 120 & 200 \\
\hline Iran & $4-12^{\mathrm{iv}}$ & 22 & 220 \\
\hline Saudi Arabia & none $^{\mathrm{ii}}$ & 0 & 150 \\
\hline Turkey & 21 & 60 & 120 \\
\hline Thailand & $20-25^{\text {iv }}$ & 50 & 110 \\
\hline Germany & $49^{\mathrm{iv}}$ & 550 & 450 \\
\hline Italy & $35^{\mathrm{v}}$ & 230 & 270 \\
\hline France & $37^{\mathrm{v}}$ & 210 & 220 \\
\hline World & N/A & N/A & 16,000 \\
\hline
\end{tabular}

Notes: i) The United States has pulled out of the deal; ii) No absolute target; iii) Pledge is above current lev$\mathrm{el}$, no reduction; iv) Upper limit dependent on receiving financial support; v) EU joint pledge of $40 \%$ compared to 1990 .

g 7.g. The UNFCCC framework with yearly reunions-COPs-is inefficient due to heavy transaction costs. Promises but no results! The G20 group of nations should be responsible for the conduct of anti-global warming policy-making and policy implementation. They are responsible for more than 70 percent of GHGs and they have the necessary financial resources to do something concrete, like the quick elimination coal power plants.

9 7.h. Climate change presents such a formidable threat to mankind that it should not be mixed up with general developmental goals, the idea of a sustainable economy or environmentalism in general. The rise in the Keeling curve must be halted-otherwise the point in time of Hawking irreversibility, conducive to 
global chaos.

g 7.i. It is time to stop the meaningless killing and destroying in the Koranic world, from Nigeria to Afghanistan, as well as time for peaceful interaction in the Korean peninsula and Myanmar. All efforts should be concentrated upon anti-global warming policy-making and implementation.

g 7.j. The making and implementation of anti-global warming policy should not rest upon the UNFCCC-transaction cost heavy framework, but with the G20 group of nations, responsible for more than 70 per cent of $\mathrm{CO}_{2}$ emissions.

g 7.k. The COP21 project amounts to nothing but all too weak international coordination, and it neglects the coming methane emissions.

\section{References}

Besson, S., \& Tasioulas, J. (Eds.) (2009). T and He Philosophy of International Law. Oxford: Oxford U.P.

Crawford, J., \& Koskenniemi, M. (Eds.) (2012). The Cambridge Companion to International Law. Cambridge: Cambridge University Press.

https://doi.org/10.1017/CCO9781139035651

Dobner, P., \& Loughlin, M. (2012). The Twilight of Constitutionalism? Oxford: Oxford University Press.

Dunoff, J. L., \& Trachtman, J. P. (Eds.) (2009). Ruling the World? Constitutionalism, International Law, and Global Governance. Cambridge: Cambridge University Press. https://doi.org/10.1017/CBO9780511627088

Gleick, J. (1988). Chaos: Making a New Science. New York: Penguin.

Goldsmith, J. L., \& Posner, E. A. (2006). The Limits of International Law. Oxford: Oxford U.P.

Krisch, N. (2011). Beyond Constitutionalism: The Pluralist Structure of Postnational Law.

Lorenz, E. N. (1969). Three Approaches to Atmospheric Predictability. Bulletin of the American Meteorological Society, 50, 345-349.

Posner, E. A. (2009). The Perils of Global Legalism. Chicago: University of Chicago Press. https://doi.org/10.7208/chicago/9780226675923.001.0001

Weber, M. (1978). Economy and Society (Vol. I-II). Berkeley, CA: University of California Press. 